\title{
Comparing Reforms of Juvenile Justice in Bangladesh and Malaysia
}

\author{
Nahid Ferdousi \\ Bangladesh Open University \\ semail correspondence: nahid329@yahoo.com
}

\begin{abstract}
The article attempts to critically compare juvenile justice reforms in both jurisdictions of Bangladesh and Malaysia. It explores legal reforms in line with the international standards to ensure the effective juvenile justice system as well as child well-being in the respective legal systems. The juvenile justice practice of Bangladesh and Malaysia are a testament that diverse juvenile laws, norms and systems exist. After ratification of UNCRC, significant progress has been achieved in both countries. Malaysia adopted mechanisms for rehabilitation in terms of job-based education and alternatives measures by the Child Act 2001. Child-oriented justice and alternative measures have started with the commencement of Children Act 2013 in Bangladesh. For both countries, there is a need for establishing a child-friendly justice system, which would ensure sustainable juvenile justice.
\end{abstract}

Keywords: Juvenile; Justice; Reforms;

Date of Submission: December 04, 2019

Date of Publication: April 20, 2020

DOI: http://dx.doi.org/10.33096/siil.v3i1.52

\section{INTRODUCTION}

Juvenile justice system has changed all around the world within a period of time. International instruments clarified that there should be a specialized system of juvenile justice adhering to fair justice policy including equal rights to every child. Children have the rights to get justice on the basis of their age, maturity, circumstances and needs. International human rights law has specific guidelines, rules and principles, which provide practical guidelines for the implementation of the UNCRC in particular areas ${ }^{1}$ State parties, too have made efforts to implement its obligations. The juvenile justice system ${ }^{2}$ has different views but in the South-east regions of Asia particularly in Bangladesh and Malaysia, the differences are slight.

\footnotetext{
${ }^{1}$ The specific rights of children in contact with the justice system are specified in Articles 37, 39 and 40 of the UNCRC, which requires the State to establish a minimum age of criminal responsibility; to hold children indetention only as a measure of last resort and for the shortest period of time; to apply allappropriate measures to promote child victims' recovery and social reintegration; and to foster theirhealth, self-respect and dignity.

2 'Juvenile Justice System' means access to justice by children under 18 years. The justice system will not only cover the treatment of the offender children but also address the root causes of the offenses as well as implement appropriate measures to prevent unusual behaviour.
} 
In enacting the juvenile legislation, Bangladesh is far behind from the other developing countries in Asia. Vietnam was the first country in Asia and the second in the world to ratify the UNCRC in 1990 and had achieved remarkable headway in promoting children's development. ${ }^{3}$ Malaysia (1995), Indonesia (1997) and India (2000) have adopted the UNCRC long before and are now trying to develop juvenile justice legislation. ${ }^{4}$ After a long period of the ratification of UNCRC, ${ }^{5}$ the Children Act $2013^{6}$ is established separate juvenile justice system along with childfriendly supportive units in Bangladesh. Both the countries are working towards establishing a separate child-friendly justice ${ }^{7}$ system on the basis of UNCRC to protect as well as to meet children's unique needs.

The reformed juvenile justice systems in both countries are not integrated with the ethical aspects in their respective legal systems. Indeed, effective juvenile justice could mean providing a morally and legally appropriate response to criminal behaviour by children and youth. In addition, children and youth have the power to change the social values and to develop nation peace building. ${ }^{8}$ Hence, their interest and rights need to be protected by the family, the community and the State as a whole. Similarly, it is needed to implement the practitioner's personal values in relation to the professional issues of child and youth care practice. The article explores how the countries of South and South-East Asia (Bangladesh and Malaysia) are reforming with international standards and what advances have been made in law and legal frameworks in both countries to be replicated in order to facilitate a holistic and vibrant child protection regime.

Children, both in Bangladesh and Malaysia, have been the subjects of legislations. In fact, both jurisdictions have several laws that are applicable to or deal with children. After the independence in 1971, the Constitution of Bangladesh 1972 laid down the general principle regarding the protection of children and others from all forms of discrimination. ${ }^{9}, 10$ The Constitution of Bangladesh is the supreme law of the land. Part III of the Constitution is especially

${ }^{3}$ Pham, T. T. N. (2013). The establishment of juvenile courts and the fulfilment of Vietnam's obligations under the convention on the rights of the child. Australian Journal of Asian Law, 14(1), p. 4.

${ }^{4}$ Child Protection and Child Welfare Services in Malaysia, Beijing High Level Meeting, Ministry of Women, Family and Community Development, November 4-6, 2010, p. 2.

5 The Convention on the Rights of the Child (UNCRC) adopted by the United Nations, General Assembly, 20 November 1989, The Convention came into force on 2 September 1990 in Bangladesh. Nevertheless, after 23 years of ratification, UNCRC was implemented in the Bangladesh legal system.

${ }^{6}$ The Children Act 2013 (Act no. 26 of 2013).

7 The Council of Europe approved (17 November 2010) Guidelines on Child-friendly Justice and provides the following useful definition: "Child-friendly Justice' refers to justice systems which guarantee the respect and the effective implementation of all children's rights at the highest attainable level bearing in mind the principles listed below and giving due consideration to the child's level of maturity and understanding and the circumstances of the case. It is, in particular, justice that is accessible, age appropriate, speedy, diligent, adapted to and focused on the needs and rights of the child, respecting the rights of the child including the rights of due process, to participate in and to understand the proceedings, respect for private and family life and to integrity and dignity."

${ }^{8}$ McShane, M. D., \& Williams III, F. P. (Eds.). (2002). Encyclopedia of juvenile justice. SAGE Publications. p, 119

${ }^{9}$ Article 27 of the Constitution declares that all citizens are equal before law and are entitled to equal protection of law. So, children are no exception of the constitutional guarantee.

${ }^{10}$ Khan, B. U., \& Rahman, M. M. (2008). Protection of Children in Conflict with the Law in Bangladesh. Save the Children UK, Bangladesh Programme. 
relevant. It contains a few provisions that address the issues of child rights, welfare, development and protection.

Though the juvenile justice system of Bangladesh was started by the Children Act 1974 but the Act 1974 has been repealed by the Children Act, 2013. Many concepts regarding children law (such as the age of criminal responsibility, restorative justice, diversion, and alternative measures on the rehabilitation of the child offender) was absent in the Act $1974 .{ }^{11,12,13}$ In fact, before signing the UNCRC, there was no legal and judicial attention on children and juvenile justice system in the country. Thus, there was no opportunity to care, protection, development and rehabilitation with education for the offender children. Often they were victim of social injustice, consequently they deprived of their childhood.

Having signed the UNCRC, children issues have been incorporated into the national planning as well as from 1992, the government formulated National Plan of Action for Children (NPA) which provided the assessment and the monitoring of the progress of the well-being and rights of the children. Thereafter, the High Court Division of the Supreme Court in Bangladesh paid attention to the children case and the High Court Division prescribed specific instructions for the system improvement as mandated by the children law. ${ }^{14}$ Therefore, the development of the children laws in line with international standards has been considered in the case of State vs. Md Roushan Mondal ${ }^{15}$. In the case, the High Court Division specified some directives for child-friendly approaches and the judgment seems to be the first one in which a number of international instruments have been elaborately discussed and taken into consideration. These legal directions have changed the course of juvenile justice system in the country. During the 2000 to 2010 there were the movement towards the separate treatment of the children. Thereafter, the government enacted the National Children Policy in 2011 along with the Children Act 2013 on the basis of the UNCRC to protect the best interests of the children.

${ }_{11}$ Ali, M. I. (2010). Towards a Justice Delivery System for Children in Bangladesh: A guide and Case law on Children in Conflict with the Law. UNICEF Bangladesh. pp. 17-23.

${ }^{12}$ Wahid, J., \& United Nations Asia and Far East Institute for the Prevention of Crime and Treatment of Offenders. (1978). Treatment of Juvenile Delinquents and Youthful Offenders In Malaysia (From Unafei-Resource Material Series No 14, 1978, SEE NCJ-51514).

${ }^{13}$ UNICEF. (2013). The Malaysian juvenile justice system: a study of mechanisms for handling children in conflict with the law. Ministry of Women, Family and Community Development and UNICEF Malaysia.

${ }^{14}$ Suo Moto Order No.248, 2003; 11 BLT 2003 HCD 281.

${ }^{15} 59$ Dhaka Law Reports (DLR) 2007, p. 72. 
Malaysia's first step to comply with UNCRC ${ }^{16}$ is based on the Juvenile Courts Act $1947^{17}$ but was effectively repealed by the Child Act $2001,{ }^{18}$ which came into force in August $2002^{19}$. Initially there were reservations made to 12 of the articles but there were inconsistencies with the country's constitution, national laws and policies. Afterwards, four of those reservations were removed and now the total numbers of reservations are eight. ${ }^{20}$ This shows the government's commitment towards the child protection system in the country. ${ }^{21}$

This framework has been improved with the National Policy on Children and the National Child Protection Policy as well as Action Plans ${ }^{22}$ in 2009. The government's fundamental objective of formulating this National policy was to establish an effective and operational child protection system in the country. ${ }^{23}$ These two policies aim to assemble intra and inter-ministerial involvement to address the needs of the children and the community and also to maximize the efforts and leverage of the roles of the private sector, media, civil society and the community. It also encourages a systematic approach towards the advocacy and building of the evidence to help make in-depth analysis related to children and recommend interventions that would advocate the children's well-being. These two policies replaced by the 1991-2000 National Plan of Action for Children that were linked to objectives and strategic visions of the National Mission of Wawasan 2020 (Vision 2020).

The previous discussion demonstrated that after the ratification of the UNCRC, children related laws within the juvenile justice system were not consolidated in Bangladesh and the children received the same treatment as the adults. But in Malaysia, laws relating to juvenile justice have been enacted just after the ratification of UNCRC, with the introduction of the Child Act 2001. This was a positive step to protect the rights of the children in all spheres of life. On the contrary, the specialised court, child-friendly procedures and distinctive disposition measures

${ }^{16}$ Malaysia ratified the UN Convention of the Rights of the Child (UNCRC) on 17 February 1995, and the first country report on the implementation of the UNCRC was presented to the United Nations Committee on the Rights of the Child in 2007 and the second report is submitted to the Committee in 2012

17 The Juvenile Courts Ordinance 1947 was implemented on December 1, 1949 in Malaysia. It was passed to combat the problem of juvenile delinquency, a social phenomenon that increased significantly in the aftermath of the Japanese Occupation in Malaysia. This Act was instrumental in the establishment of the first court that caters specificallyto children, the Juvenile Court, which is currently known as the Court for Children, renamed by virtue of the Child Act 2001, which repealed the earlier Juvenile Courts Act 1947.

${ }^{18}$ The Child Act 2001(Act No. 611).

${ }^{19}$ The Child Act 2001 consolidated three former Acts, namely, the Juvenile Courts Act 1947 (The Act to establish the Juvenile Court and deal with child offenders), the Women and Young Girls Protection Act 1973(Act to protect women and children exposed and involved in immoral vices) and the Child Protection Act 1991(Act to provide care and protection to children). For details on the background of this Court, see Farah Nini Dusuki, 'Perkembangan Mahkamah bagi KanakKanak,' in Farid Sufian Shuaib, Perkembangan Perundangan Malaysia: Artikel Terpilih, Jilid 2, 2007, p. 125.

20 In 1998, Malaysia withdrew 5 reservations i.e. Articles 22, 28 (1) (b), (c), (d) and (e), 40(3) and (4), 44 and 45. Subsequently, in July 2010, Malaysia withdrew 3 more reservations i.e. Articles 1, 13 and 15 leaving 5 remaining reservations (Articles 2, 7, 14, 28(1) (a) and 37).

${ }^{21}$ Farah Nini Dusuki, The UN Convention on the Rights of the Child and The Administration of Juvenile Justice: An Examination of the Legal Framework in Malaysia, Asia Law Quarterly, 2009, Vol. 1, No.1, p. 141.

${ }^{22}$ The National Policy on Child Protection and Action Plan 2009.

${ }^{23}$ The policies were formulated by the Ministry of Women Family and Community Development (MWFCD) in 2009. Objectives of the policies highlight the rights of children to survival, protection, development and participation, all of which are in-line with the UNCRC. 
adopted in the Act 2013 in Bangladesh. It reflects the country's commitment towards the minimum global standards of child protection and child rights enshrined in the UNCRC.

\section{METHOD}

In this section, the author attempts to undertake a comprehensive comparison of the juvenile justice practice in Bangladesh and Malaysia. In this context this study assesses the legislation, procedural matters relating to the age of criminal responsibility, conditions for arrest and detention, specialized institutions for juvenile justice, probation service, juvenile courts and trial procedures, diversion and alternative sentencing and re-integration and rehabilitation policy of both countries. These are described below.

\section{ANALYSIS AND DISCUSSION}

\section{The Minimum Age of Criminal Responsibility}

Age of criminal responsibility is the most important factor in treating the child as a juvenile delinquent. In UNCRC, there is no such general consensus in specifying the age of criminal liability for children. Article 40 of the UNCRC allows State parties to exercise their discretion to determine the minimum age of criminal responsibility, ${ }^{24}$ the Committee on the Rights of the Child has on numerous occasions urged States to adopt an upper age limit to offer greater protection to children. The Beijing Rules do not set out any particular minimum age of criminal responsibility but recommends that the commencement age for criminal responsibility should not be fixed too low, bearing in mind the facts of emotional, mental and intellectual maturity. ${ }^{25}$

In its General Comment 19, the UNCRC recommended 12 years old as the acceptable minimum age of penal infringement and deplored countries that placed the minimum age of criminal responsibility lower than this because the UNCRC found it unacceptable by international standards. The Committee has urged State parties to increase the minimum age to the preferable age of 18 years old, and has duly justified this stance by recognizing the developmental differences and decision-making capabilities of children and youth. ${ }^{26}$

In Bangladesh, the Penal Code, 1860 deals with the presumption of innocence in respect to juveniles, subject to certain qualifications of the age specified in sections 82 and $83 .{ }^{27}$ The age

24 Article 40(3) provides that "States Parties shall seek to promote the establishment of laws, procedures, authorities and institutions specifically applicable to children alleged as, accused of, or recognized as having infringed the penal law, and, in particular: (a) The establishment of a minimum age below which children shall be presumed not to have the capacity to infringe the penal law".

${ }_{25}$ Rules, Beijing. (1985). United Nations Standard Minimum Rules for the Administration of Juvenile Justice. Adopted by the General Assembly on, 29, Rule 4.1.

${ }^{26}$ Unicef. (1998). Innocenti Digest No. 3. Juvenile Justice Unicef: Florence. p. 5.

${ }^{27}$ Section 82 provided that any children under the age of 7 years are immune from any trial for offense committed by them and subsequent punishment. According to Section 83, an offense is not to be tried if committed by a child above 7 years of age and under 12, who has not attained sufficient maturity of understanding the nature and consequences of his conduct on that occasion. Once the child has attained the age of 12 , he or she is fully responsible for his or her actions. 
of criminal responsibility in Bangladesh is problematic. Firstly, it is set extremely low, 9 years ${ }^{28}$ of age, with the provision of doli incapax (where it must be proved that children within a certain age bracket are above the minimum age of criminal responsibility and have the required maturity to be deemed criminally responsible) applied for children between 9 and 12 years of age.

In Malaysia according to the Child Act 2001, the definition of child criminal is, a person under the age of 18 who has attained the criminally responsibility as prescribed in section 82 of the Penal Code. ${ }^{29}$ The Penal Code stipulates 10 to be the age of attainment of criminal responsibility ${ }^{30}$ but the children between 10 and 12 years of age who have not shown sufficient maturity may be absolved of criminality as well. ${ }^{31}$ Thus, as per the Penal Code, the children under the age of 10 years are not criminal responsible for their actions. It also includes that any act of a child who is above 10 and less than 12 years of age is not an offense if the child has insufficient maturity to understand and judge the nature and consequences of her /his conduct. It is, however, depending upon his level of understanding as to the nature and consequence of his act at the time of the commission of the crime. ${ }^{32}$ Whilst in the Shariah Court, the criminal responsibility of a person is determined upon attaining the age of puberty according to Islamic Law. The discussion of the Muslim jurists maintains that the criminal responsibility of a child begins at the age of 7 years and continues to be treated as a child until he attains puberty. On the issue of determining the age of puberty, there are two main views; one is 15 years old and the other is 18 years old. Meanwhile, the Syariah Criminal Procedure (Federal Territories) Act 1984 interprets "youthful offender" as an offender above the age of 10 and below the age of 16 years.

However, the minimum age of criminal responsibility or doli incapax in both jurisdictions is lower than that of the international standards. As in many other countries, provisions that were intended to limit the criminal liability of children between the ages of 9 and 12 are not rigorously applied and there is no standard process by which the court makes assessments of maturity based on the advice of a psychologist or any other expert. The UN Committee on the Rights of the Child expressed concern with the low minimum age of criminal responsibility and recommended that Bangladesh and Malaysia raise the age to at least 12 years. ${ }^{33}$

\section{Conditions for Arrest and Detention}

As per the international instruments, the rights for children are the right to be treated with dignity, ${ }^{34}$ the right to life,${ }^{35}$ the right to be presumed innocent, ${ }^{36}$ the prohibition of torture and ill-

${ }^{28}$ In 2004, the government has amended the Penal Code, 1860 and raised the minimum age of criminal responsibility of a child from 7 to 9 years.

${ }^{29}$ See generally Child Act 2001, particularly Part X and XIII on criminal procedure for children.

${ }^{30}$ The Penal Code (Act 574), Sec 82.

${ }^{31} \mathrm{Ibid}$.,Sec 83.

${ }^{32}$ Shaikh, M. A. (1988). Ethics of Decision-Making in. American Journal of Islamic Social Sciences 5: 1, 5(1), 115.

${ }^{33}$ Farah Nini Dusuki, The UN Convention on the Rights of the Child and The Administration of Juvenile Justice: An Examination of the Legal Framework in Malaysia, 146.

${ }^{34}$ The Rules Beijing, Op.Cit, Rule 13.

${ }^{35}$ The UNCRC, Art 6.

${ }^{36}$ The UN Rules for the Protection of Juveniles Deprived of their Liberty 1990, Rule 17. 
treatment of children, the avoidance of the use of harsh language and physical violence are to be respected at all times. In Bangladesh, the Act 2013 specifies responsibilities of the designated police officer and gives the responsibility for the establishment of a "Child Affairs Desk" ${ }^{37}$ headed by a "Child Affairs Police Officer" (CAPO) to the Ministry of Home Affairs. According to the Act, children under age of 9 cannot be arrested. If any child above age 9 is arrested, the use of handcuff and ropes are completely forbidden. Additionally, the same charge sheet cannot be used for both children and adults.

At the very first instance, the police officer dealing with the child has the responsibility to consider bail. If the offense alleged is bail able, then bail is to be granted because this is a right. Where the child is not released on bail, the CAPO shall take steps to produce the child before the nearest children's court within 24 hours. ${ }^{38}$ When the child is produced before the children's court, the court shall either release him on bail or order for his detention in a safe home or a Child Development Centre (CDC). ${ }^{39}$ However, rights' relating to the protection of children in detention is included in Articles 32, 33 and 35 of the Constitution of Bangladesh. ${ }^{40}$ Similar safeguards can be found in sections 60 and 61 of the Code of Criminal Procedure $1898 .{ }^{41}$

In addition, the Act 2013 covers many aspects of children's vulnerability in detention stages. The Act introduces new provisions regarding the CAPO who maintains separate treatment of the offender child. ${ }^{42}$ Lack of Children Rules, insufficient CDCs, ${ }^{43}$ lack of ethical guidelines of treatment of child and youth offenders, the children rights are continuously being violated once they are kept in jails. ${ }^{44}$ During detention period, children suffer higher rates of physical and sexual abuse by the police, staff and adult inmates, which is the contravention of article 37(a) of UNCRC. 45

${ }^{37}$ The Children Act 2013, Sec13.

${ }^{38}$ The Children Act 2013, Sec 52(4).

39 The Children Act 2013, Sec 52(5).

${ }^{40}$ Article 32 of the Constitution of Bangladesh provides the protection of the right to life and personal liberty of a person. Article 33 (2) states that every person who is arrested and detained in custody shall be produced before the nearest magistrate within a period of twenty-four hours of such arrest... and no such person shall be detained in custody beyond the said period without the authority of a magistrate. Article 35 provides for protections in respect of speedy trial and punishment, and expressly prohibiting torture and cruelty, degrading, inhuman treatment or punishment.

${ }^{41}$ Section 60 of the Criminal Procedure Code provides that a police officer arresting a person must produce him before the Magistrate having appropriate jurisdiction. Section 61 provides that a police officer must not detain an arrested person for more than twenty-four hours without the authority of a magistrate.

42 The Children Act 2013, Sec 14

43 At present, there are three Child Development Centers (CDCs) in Bangladesh for the rectification and rehabilitation of children, which are not sufficient to meet the needs ofthe whole country. Two of them were established at Tongi in 1978 and Jessore in 1995 for male children. The third centre was established in Konabari, Gazipur in 2003 for girls. Each centre consists of one remand home, one juvenile court and one training institute.

${ }^{44}$ Hoque, M. E. (2009). Best Interest of the Children. Dhaka: Academic Press and Publishers Library, 3, 21. p.18.

${ }^{45}$ Article 37 of the UNCRC limits the use of detention: (b) No child shall be deprived of his or her liberty unlawfully or arbitrarily. The arrest, detention or imprisonment of a child shall be in conformity with the law and shall be used only as a measure of last resort and for the shortest appropriate period of time; (c) Every child deprived of liberty shall be treated with humanity and respect and shall be separated from adults unless it is considered in the child's best interest not to do so and he /she shall have the right to maintain contact with his or her family through correspondence and visits, save in exceptional circumstances. 
The Malaysian Constitution guarantees everyone the right to be protected from deprivation of liberty except in accordance with the law. ${ }^{46}$ Under Malaysian law, a person may be arrested by the police with or without a warrant. ${ }^{47}$ If a person forcibly resists such arrest or tries to escape, the police may use all means necessary to affect the arrest. ${ }^{48}$ These legal provisions apply equally to both children and adults and there is no special provision in law restricting the use of formal arrest or force while handling children. The probation officer and the child's parent, however, must be notified immediately after the arrestment of the child offender. ${ }^{49}$

Malaysian Act 2001 does not include specific provisions with respect to the length of time that the children may be held in police custody for investigation, other than the requirement that they are brought before a Magistrate within 24 hours. Section 84 of the Act 2001 states that a child who is arrested must be brought before a court for children (or if this is not possible, before a magistrate) within 24 hours, and that the court must release the child on a bond executed by her/his parents (with or without requiring a cash deposit) in an amount that the court feels is sufficient to ensure that the child returns to court for her/his hearing, unless: a) the child is charged with one of the listed grave crimes; ${ }^{50} \mathrm{~b}$ ) it is necessary for the best interests of the child to remove her/him from association with any undesirable person; or c) the court has reason to believe that the release of the child would defeat the ends of justice.

However, the Act 2001 also states that, where a child is detained at a police station, appropriate arrangements must be made to prevent the child from coming into contact with the adult offenders, and to protect the child's privacy from the media. ${ }^{51}$ Release on bail is also prohibited for certain serious offenses, regardless of the child's age or personal circumstances. In its concluding observations to Malaysia's country report under the UNCRC, the UN Committee on the Rights of the Child expressed its concern regarding long pre-trial detention periods and delays in dealing with cases involving children. The Act states that places of detention are to be governed by separate regulations and inspections. ${ }^{52}$ However, while regulations have been issued with respect to the "places of safety", as yet there is no specification to the "places of detention" for children. Although the Act 2001 includes provisions designed to ensure that the children be sentenced to prison only in relation to the very serious crimes, there is no similar protection with respect to the use of prisons as a place of remand. As a result, many children

${ }^{46}$ The Constitution of Malaysia, Art 5.

${ }^{47}$ The power to arrest without a warrant is quite broad, including the arrest of "any person who has no ostensible means of subsistence or who cannot give a satisfactory account of himself". Preventative detention is also authorised under the Internal Security Act 1969, the Emergency (Public Order and Prevention of Crime) Ordinance 1969, and the Dangerous Drugs (Special Preventative Measures) Act 1985.

${ }^{48}$ The Police Act 1967 (Act No. 344), Sec 27.

${ }^{49}$ The Child Act 2001, Sec 87(1)(a).

${ }^{50}$ Murder, culpable homicide, attempted murder, an offense under the Firearms (Increased Penalties) Act, 1971, and offenses under the Internal Security Act 1960 punishable with imprisonment for life or with death; an offense under the Dangerous Drugs Act 1952 punishable with imprisonment for more than five years or with death, and an offense under the Kidnapping Act 1961.

51 The Child Act 2001, Sec 85.

52 lbid., Sec 86. 
charged with very minor offenses are being exposed to prison life and held together with young offenders up to 21 years of age who have been convicted of very serious offenses. ${ }^{53}$

When a person is arrested, the police must without unnecessary delay either release the person on bail, or bring them before a magistrate within 24 hours. ${ }^{54}$ If the person is arrested for a "bailable" offense, the police may either release the person on their own bond, or hold them in police detention while conducting the investigation. Decisions about whether to release a person on "police bail" are made by an inspector and release at this stage does not require the deposit of a cash bond. ${ }^{55}$ As a general rule, the investigations must be completed within 24 hours.

However, the CrPC protection does not apply to children between the ages of 16 and 18 and the Act 2001 is silent on this point. Children who are not released on bail are remanded pending their trial to a "place of detention". Thus, there is no statutory limit under either the CrPC or the Act 2001 regarding the length of time a child can be held on remand awaiting their trial. There is no detailed guideline or directive guiding magistrates in exercising their discretion to grant bail to children and it is unclear that the extent to which magistrates can apply the special provisions of the Act 2001 rather than the regular bail provisions of the CrPC. ${ }^{56}$

\section{Specialized Institutions for Juvenile Justice}

Delinquent children in correctional institutions must receive care, protection and all the necessary social, educational, vocational, psychological, medical and physical programs and services. ${ }^{57}$ However, in Bangladesh, as a part of the justice system, the children correctional governance is not developed in accordance with international standards. At present, there are three Child Development Centres (CDCs) under the Department of Social Services (DSS) in the Ministry of Social Welfare (MoSW) of Bangladesh. The first one was established at Tongi in 1978, another at Pulerhat, Jessore in 1995 (both for male children) and the other at Konabari, Gazipur in 2002 (for female children). ${ }^{58}$ Every CDC consists of one remand home, one juvenile court and one vocational training institute. Expect primary education, there is no secondary education facility which encourages responsible behavior among children. Two categories of children are kept there, the first category includes uncontrollable children who are referred by parents and the second category comes to the CDC after having committed offenses and being referred by the courts. ${ }^{59}$ There is no other rehabilitation center in the whole country.

${ }_{53}$ Section 49 of the Prison Act states that inmates shall not ordinarily be associated with prisoners serving their sentences of imprisonment or be required to labour, and that young prisoners (defined as those under 21 years of age) shall, so far as local conditions permit, be kept apart from adult detainees

54 The CrPC, Sec 28.

55 Ibid.,Sec 29.

${ }^{56}$ Selvi Supramaniam (edited), "Malaysian Juvenile Justice System:A Study of Mechanisms for Handling Children in Conflict with the Law", 46.

${ }^{57}$ According to Beijing Rule 26 the objective of institutional treatment is to provide care, protection, education and vocational skill, with a view to assist the juvenile to assume a socially constructive role in society.

${ }^{58}$ Hoque, M. E. (2009). Best Interest of the Children. Dhaka: Academic Press and Publishers Library, 3, 21, p.63.

${ }^{59}$ www.msw.gov.bd/ (accessed on January 18, 2018). 
In reality most of the inmates are frequently abused or have to face ill-treatment in the CDCs. Sometimes they rebel against the authority of the CDCs. For example, on 12 February and 4 May 2013, the inmates in the Tongi and Jessore CDCs slashed themselves in a similar fashion to protest against the torture by their supervisor. ${ }^{60}$ Incidences such as these are obvious signs of the non-systematic management and unethical approach of the CDCs. The Third and Fourth periodic reports submitted by Bangladesh to the UNCRC Committee also admitted that the CDCs require better logistics support since the resources are not adequate and stated that "there are shortages of training facilities for children, and the general physical conditions of the children and overall atmosphere are not up to the mark" ${ }^{61}$ Thereafter, the Act 2013 states that the government is obliged to establish and maintain a necessary number of child development centers for both male and female children. The government shall also ensure the minimum standards for proper care of the children staying in the institutes. ${ }^{62}$ However, this mandate is yet to be implemented.

On the contrary, in Malaysia, the Act 2001 provides for four different types of institutions for child offenders, with varying degrees of security. They are probation hostels, ${ }^{63}$ approved schools, or Sekolah Tunas Bakti (STBs), ${ }^{64}$ Henry Gurney schools ${ }^{65}$ and prisons. ${ }^{66}$ Malaysia currently has eleven probation hostels (three for girls and eight for boys) and nine STBs (six for boys and three for girls) operated by the Department of Social Welfare, as well as two Henry Gurney Schools and six juvenile rehabilitation centers operated by the Department of Prisons. Probation hostels cater to children under remand, children in transit to an STB and children under a court order of detention for twelve months because they have committed a crime or are "beyond control". They are generally smaller in size than the STBs, with a capacity of between 50 and 80 children. Stakeholders advised that the probation hostels generally operate below capacity and that the majority of children are generally on remand, rather than on probation order. Sekolah Tunas Bakti, or STBs cater to child offenders, children who are beyond control, and sometimes children on remand. ${ }^{67}$ They are generally large-scale facilities with a capacity of between 100 to 200 children. The nine STBs nationwide have a total capacity for 1,200 children. Since 2003, the

60 The Daily Star, Torture on the young: correctional centers need corrective steps: Body to probe correction centre's misconduct, 16 February 2014, 6.

${ }^{61}$ UNCRC Committee (2008) 'Third and fourth periodic reports of Bangladesh submitted to the Convention on the Rights of the Child', UNCRC/C/BGD/4, 23 October 2008, 31 (accessed on 19 March 2014).

62 The Children Act 2013, Sec 63.

${ }^{63}$ TheChild Act 2001, Sec 61(1). Probation Hostels are guided by the Probation Hostels Regulation 1982.

${ }^{64}$ The Child Act 2001, Sec 65(1). The Act states that STB shall be established for the education, training and detention of children. The STBs are also designated and gazetted by the Ministry of Social Welfare and subject to the regulation, management and inspection of the JKM. They are guided by the approved School Regulations 1981.

${ }^{65}$ Henry Gurney Schools are operated by the Prisons Department and follow a higher security regime than the STBs. They are governed by the Henry Gurney School Rules 1949.

${ }^{66}$ The Child Act 2001, Sec 96(3): Children subject to an order of imprisonment are placed in a Youth Rehabilitation Centre operated by the Department of Prisons. The Child Act states that a child ordered to be imprisoned shall not be allowed to associate with adult prisoners.

${ }^{67}$ Selvi Supramaniam (edited), "Malaysian Juvenile Justice System:A Study of Mechanisms for Handling Children in Conflict with the Law", 110. 
STBs have consistently housed over 1,000 children. ${ }^{68}$ As with the probation hostels, STBs generally operate under capacity. ${ }^{69}$ The Henry Gurney School is an advance approved school for the detention of child offenders who have attained 14 years of age and have yet to reach 21 years old. The period of rehabilitation is not more than three years. ${ }^{70}$ However, the period of rehabilitation may be extended until the child offender reaches 21 years old.

\section{Probation Authority}

Probation authority that deals in special ways with children is very important for a fair juvenile justice system. The probation order is an order requiring the person to be under the supervision of a probation officer for a period not less than one year and not more than three years, as specified in the order. ${ }^{71}$ In this perspective, the Act 2013 prescribes the provision relating probation officers, ${ }^{72}$ more specifically with the appointment, responsibilities and duties of probation officers in Bangladesh. The Act 2013 provides that the government shall appoint at least one or more probation officers in every district, sub-districts or metropolitan area. In any case, when children in conflict with the law are sent to a CDC or any certified institute, it is the duty of the probation officer to prepare and preserve a separate file for each child, and to follow the procedure for alternative care. ${ }^{73}$ Within 21 days of production of the child before the children's court, the probation officer is mandated to submit before the court a social enquiry report in the like manner prescribed by the Children Rules. ${ }^{74}$

In Malaysia, according to the Act 2001, a copy of the charge and related documents has to be provided to the probation officer to assist him in preparing an informative probation report. ${ }^{75}$ The Act 2001 also makes it compulsory for the children court to consider a probation report before making an order against the child and to consider the opinion of the court advisors. The probation officer must include information regarding the child's general conduct, home surroundings, school records, and medical history. The UNCRC obligates State parties to create mechanisms, systems and authorities that specially cater to children alleged to have infringed the prevailing penal law. Similarly, for establishing wellbeing of the children, appropriate and competent bodies and personnel have to be created as well. ${ }^{76}$ It can be said that, in the case of both countries, there is grave insufficiency of probation services.

\footnotetext{
${ }^{68}$ Department of Social Welfare, 2008.

${ }^{69}$ Selvi Supramaniam (edited), "Malaysian Juvenile Justice System: A Study of Mechanisms for Handling Children in Conflict with the Law", 110.

${ }_{70}$ Child Act 2001, Sec 75(2)

71 The Probation of Offenders Ordinance 1960, Sec 10 (1).

72 The Children Act 2013, Sec 5.

73 lbid.,Sec 84.

74 Ibid.,Sec 31.

75 The Child Act 2001, Sec 87.

${ }^{76}$ Article 3 provides that "States parties shall ensure that the institutions, services and facilities responsible for the care or protection of children shall conform to the standards established by competent authorities, particularly in the areas of safety, health, in the number and suitability of their staff, as well as competent supervision."
} 


\section{Juvenile Courts and Trial Procedures}

The Act 2013 stipulates the functions and powers of the separate children court in Bangladesh. The entire crux of the juvenile justice system rests on expeditious justice and trial process in the best interests of the child. There are only three separate children courts: one for female children and the remaining for male children. The first two children courts for boys were established in Tongi (1978) and Jessore (1995) and only one children court for girls established in Konabari (2002) respectively. ${ }^{77}$ Except these three children courts in the country, there is no separate children court which could ensure that children are separated and treated differently from the adults at all stages of the criminal proceedings.

As per the Act 2013, at least one court is to be established in every district in the country. ${ }^{78}$ The court shall arrange for appropriate seating arrangements for the child and in case of a challenged child, where necessary, provide special seating arrangements. While the trial of a child is in progress, the lawyer, police or any other official present in court shall not wear any professional or official uniform. ${ }^{79}$ It needs to be mentioned here that the government has established the children court in the additional session judge court in every district, said a notification which was issued by the Ministry of Law, Justice and Parliamentary Affairs on 24 April 2014. However, where an adult is jointly involved with the child, the trial of the adult shall continue ${ }^{80}$ In the Act, keeping the child in safe custody during the pendency of any trial shall be considered as the last resort and that would be done only for the shortest possible period of time, and any child kept in safe custody shall be dealt in the way of diversion within the shortest possible time. ${ }^{81}$

In Malaysia the concept of separate court for children has existed since 1947 and it was strengthen by the Act 2001. It provides the details of the child special court infrastructure, an official order for the establishment of the children's court and comprehensive trial procedure in respect to the children. It laid down the trial procedures before the court for children. ${ }^{82}$ The Child Act also makes it compulsory for the child's parents or guardian to attend the legal proceeding. ${ }^{83}$ If the child's parents or guardian is absent from the legal proceeding, he shall be liable to a fine of RM5000 or up to 2 years imprisonment or both.

There is a full-time court for children in Kuala Lumpur. In other districts, children's cases are heard separately by a Magistrate sitting as the court for children on specific day(s) of the week. The number of special court sittings for children varies from location to location. To minimize the children's contact with adult offenders, efforts have to be made for separate entrance

77 Borhan Uddin Khan and Muhammad Mahbubur Rahman, Protection of Children in Conflict with the Law in Bangladesh, Dhaka: Save the Children UK 2008, 66-67.

${ }^{78}$ The Children Act 2013, Sec 17(4).

79 Ibid,.Sec 19(4).

80 The Children Act 2013, Sec 32.

81 Ibid,.Sec 26

82 The Child Act 2001, Sec 90(1-18).

${ }^{83}$ The Child Act 2001, Sec 88 
to court or to select a room that is in an isolated part of the building. ${ }^{84}$ Children on remand are often transported to and from the court together with adults, due to lack of police vehicles and personnel. It is a matter of great concern that section 90 of the Act 2001 has been interpreted to mean that, unlike adults, children do not have a right to silence during the trial process and must give evidence in the proceedings. ${ }^{85}$ There is only one specialized court for children in Kuala Lumpur, which sits daily to hear cases involving children, so the trial process is speedy here but other districts do not have these facilities as they share the same magistrate court for both adults and children.

Most importantly, the court ought to have child-friendly features, befitting the intention not to stigmatize children who come into contact with the law, regardless of whether they are 'victims or villains'. Sadly, it is only in Kuala Lumpur where the only one specialized court for children, which sits daily to hear cases involving children, exists. In other states and districts, the similar court is shared between the Magistrate's Court for Adults and the court for children, with the same Magistrate 'changing hats' when required. In addition, limited hearing days may result in children not having access to a speedy trial as they need to wait for the Magistrate to be free enough to preside in the court for children. ${ }^{86} \mathrm{However}$, in the both countries legal system, the children court ensures that cases are expeditiously dealt with so that children are not placed in jail custody indefinitely, and that the backlog of cases is resolved speedily. The juvenile justice framework attempts to facilitate speedy disposal of cases as well as speedy justice rendered to the juvenile.

\section{Diversion and Alternative Sentencing}

The UNCRC has been explicit in highlighting the restorative and rehabilitative philosophy of juvenile justice. ${ }^{87}$ It has urged States to remove the death penalty for juveniles form their penal statutes and also refrain from imposing life imprisonment or imprisonment on young offenders. ${ }^{88}$ The UNCRC also urges States to eliminate and prohibit all punitive practices against children in all settings.

Bangladesh has attempted to incorporate a restorative and non-punitive attitude within its juvenile justice framework. There is no imposition of death penalty, life imprisonment or imprisonment under the Act 2013. Irrespective of the nature of offense, gravity of offense, or cases of repeat offenders, no penal sanction is authorized by the Act. All Forms of corporal punishment are also prohibited in detention centers. The Act 2013 provides that, no child shall be sentenced

${ }^{84}$ Rahman, W. U., \& Shahabuddin, M. (Eds.). (2005). Judicial Training in the New Millennium: An Anatomy of BILIA Judicial Training with Difference. Bangladesh Institute of Law and International Affairs.

85 Ibid,

86 Ibid,.Sec 11(5).

${ }^{87}$ Article 39 of UNCRC: States Parties shall take all appropriate measures to promote physical and psychological recovery and social reintegration of a child victim of: any form of neglect, exploitation, or abuse; torture or any other form of cruel, inhuman or degrading treatment or punishment; or armed conflicts. Such recovery and reintegration shall take place in an environment which fosters the health, self-respect and dignity of the child.

${ }^{88}$ Article 37 of UNCRC: States Parties shall ensure that: (a) No child shall be subjected to torture or other cruel, inhuman or degrading treatment or punishment. Neither capital punishment nor life imprisonment without possibility of release shall be imposed for offenses committed by persons below eighteen years of age; 
to death, imprisonment for life or imprisonment. But the period of sentence may not exceed the maximum period to which the child could have been sentenced. Children may be ordered to be detained in a certified institute instead of prison until he reaches the age of 18 . When a child is sentenced, s/he shall not be allowed to associate with any adult in the prison. ${ }^{89}$ Where a child is found guilty of an offense punishable with death or imprisonment for life, the children's court may order the child to be detained in a CDC for a period of not less than 3 years but not more than 10 years. However, if a child is found guilty of an offense not punishable with death or imprisonment for life, s/he may be ordered to be detained in a CDC for up to 3 years. ${ }^{90}$

Malaysia, on the other hand, the sentencing of children is governed mainly by section 90 of the Act 2001. The Act states: "A sentence of death shall not be pronounced or recorded against a person convicted of an offense if it appears to the court that at the time when the offense was committed he was a child." ${ }^{11}$ However, pursuant to the Essential (Security Cases) Regulations 1975 (ESCAR), children charged with offenses under the Internal Security Act 1960 and the Firearms (Increased Penalties) Act 1971 (FIPA) are not afforded with the special protection under the Act 2001and may be subject to capital punishment. ESCAR explicitly states that "Where a person is accused of or charged with a security offense, he shall regardless of his age, be dealt with and tried in accordance with the provisions of these Regulations and the Juvenile Courts Act (1948) shall not apply to such person". Unfortunately, the ESCAR was not amended with the Act 2001. The Act also describes the situations where children are not allowed to enjoy the benefit of special sentencing provisions. If the child turns 18 while the Court proceeding is ongoing then the Court has the right to decide whether to apply special sentence provision or adult term of imprisonment.

The Act 2001 does not include any general principle or criterion for making decisions about sentencing. However, it includes a list of the sentencing options. ${ }^{92}$ Alternatively, if a child commits an offense for which the death penalty applies, ${ }^{93}$ the child must be detained in prison indefinitely at the "pleasure of the sultans or governors". The previous version of the Act stated only that the child must be "detained", allowing for placement in Henry Gurney Schools, but the Act 2001 mandates a prison placement. ${ }^{94}$

In the case of corporal punishment, the Act 2001 and the other laws allow for whipping, which is contradictory with internal conventions. Section $91(\mathrm{~g})$ of the Act authorizes the court for children to "order the child, if it is a male, to be whipped with not more than ten strokes of a light cane- (i) within the Court premises; and (ii) in the presence, if he desires to be present, of the

\footnotetext{
89 The Children Act 2013, Sec 33.

90 Ibid,.Sec 34

91 Ibid,.Sec 97

92 The Child Act 2001,Sec 94.Good behaviour bond, custody of fit person,fine and probation order.

${ }_{93}$ Murder, certain terrorism offenses, hostage taking, waging war, mutiny, kidnapping in order to murder, gang robbery with murder, drug trafficking.

94 The Child Act 2001, Sec 97.
} 
parent or guardian of the child". ${ }^{95}$ If the child is 14 years or older and has committed an offense punishable with imprisonment, the court may order any term of imprisonment which could be awarded by a court of sessions. ${ }^{96}$ The existing legal provisions allowed punishment for the child offender, which is otherwise prohibited by the international conventions. There is no limit on the maximum term of imprisonment that may be imposed upon children who are liable to both life imprisonment and indefinite imprisonment.

\section{Re-integration and Rehabilitation Policy}

The provision of diversion has to a large extent been an integral part of the juvenile justice systems for establishing child rights and child welfare. Diversion remains an experimented area in the Bangladesh. The provision of diversion has been incorporated into the Act 2013 for the offender children at any time after their arrest. The process and procedure of diversion shall be prescribed by Children Rules. The DSS is mandated to adopt programs for the implementation of the diversionary measures. ${ }^{97}$ The Children Rules is still processing in the DSS. Though diversion system indicates to the children's physical, social, emotional, cognitive and spiritual development, but there is deficiency of fully comprehensive rehabilitation ${ }^{98}$ policies. Where diversionary measures are initiated by the probation officer, s/he may take steps for arranging a family conference in order to resolve the dispute on a priority basis. The family conference shall be considered confidential and any discussion therein shall not be evidence in any legal proceeding in any court. ${ }^{99}$ Diversion must be initiated and completed within the time fixed by the children's court or the CAPO. Howbeit, the unsatisfactory condition of the institutional treatment for child offenders in Bangladesh offers fewer possibilities for rehabilitation.

Diversion program has been introduced in Malaysia as the alternative to imprisonment for the juvenile offenders who are over 18 years old. But in the Act 2001deprivation of the liberty is forbidden. If there is no other option, only then the deprivation of liberty or custodial order may be used. The Act also includes that, a child offender under the age of 14 cannot be ordered to be imprisoned for any offense, committed to prison for failing to pay a fine, compensation or costs. For the child over the age 14 years, it states that, s/he cannot be ordered to be imprisoned; rather s/he can be dealt with any other way, such as by probation, fine or being sent to a place of detention or an approved school such as the Henry Gurney School. ${ }^{100}$ According to the Act 2001, probation officers are responsible for the supervision of children who are subject to a communitybased order. Probation officers are appointed and gazetted by the Ministry. ${ }^{101}$

\footnotetext{
${ }^{95} \mathrm{Ibid}, . \mathrm{Sec} 91(\mathrm{~g}), 92$.

96 Ibid,.Sec 75

${ }^{97}$ The Children Act 2013, Sec 48.

98 The concept 'rehabilitation' is closely associated with child rights based children justice, which aims to protect children's survival and development and rehabilitate the child/juvenile offender into the community withdignity and integrity.

${ }^{99} \mathrm{Ibid}, \mathrm{Sec} 49$

100 The Child Act 2001, Sec 93.

101 The Child Act 2001, Sec 10.
} 
The Act currently does not include any specific provisions with respect to the pre-trial diversion of children of Malaysia. However, a pursuant to the Federal Constitution, the public prosecutor has the power, exercisable at her/his discretion, to institute or discontinue the criminal proceedings, which could be used as the basis for diversion; even where there is no guideline or standard procedure to encourage the use of prosecutorial discretion in children's cases and no formal process for screening all cases for possible diversion. Support for the introduction of diversion or restorative justice programs has been growing amongst policy makers, academicians and legal practitioners. Many stakeholders have also expressed an interest in introducing family conferencing proceedings and structured diversion programs such as the guidance program of Malaysia.

The above analysis demonstrates that both jurisdictions adopt child-oriented framework for child protection and wellbeing. Their respective statutes, mechanisms and systems adequately reflect this. The Act 2013 incorporates a largely diversion component. It is a beneficial legislation meant to reform, rehabilitate and reintegrate children back into their families and society. The specialized approach adopted towards offender children in the Act 2001 and the respective policies are reflective of the country's commitment towards the minimum global standards of child protection and child rights enshrined in the UNCRC. The specialized court, child-friendly procedures and distinctive disposition measures adopted with the non-punitive framework and practices in the realm of juvenile justice.

However, there remains a significant gap between the law and its implementation to protect the best interests of the children in Bangladesh. The government of the country is yet to formulate rules of the Act 2013 despite five years having passed since it was enacted. In both countries, the present situation of community-based treatment of juvenile offenders is not satisfactory, as there are only limited options in the form of institutional arrangements. Though Malaysia has enhanced of both institutional and non-institutional machinery but there is needed to find ways of strengthening it in Bangladesh.

In light of the above situation and conditions that occur then it is expected that there are ideal steps, including:

\section{a. Proper Implementation of the Laws and Policies}

Over the years, the Bangladesh juvenile justice system has gradually improved, but still has a lot to do in this area. While comprehensive laws dealing with issues such as procedures and correctional system for child offenders are being called by new circumstances. The government authorities should act proactively to make the necessary Children Rules dealing with non-custodial sanctions in line with the General Comment of the Committee on the Rights of the Child 2007 and the Council of Europe Guidelines. ${ }^{102}$ Since the Act 2013 is inter-linked, many of

${ }^{102}$ Nahid Ferdousi, (2015) The establishment of children's courts in Bangladesh: from principle to practice, Oxford University Commonwealth Law Journal, 15:2, pp. 197-221. 
the new concepts such as diversion, family conferencing, alternative care, dispute resolution cannot be put into practice without the Children Rules. In addition, the child affairs desks in the police station and independent national child welfare boards should be setup in each district. Meanwhile, in 2017, one district level child welfare board has been established by collaboration with the DSS and UNICEF. Five more are schedule to be completed in $2018 .{ }^{103}$

It is indeed to say that as far as proper functioning of the juvenile justice system, sufficient number of certified institutes and children court is extremely important. Though at present district courts and additional district courts are working as a children court in the country but still there is no special separate children courts in Bangladesh. It can be said that once a children court is established, responsiblities of the other concerned agencies for arrest, investigation, prosecution, charge sheet, probation report, rehabilitation, after-care service, will be child-oriented and children can get child-freindly approaches from them. The operation of children courts will require childfriendly investigation, prosecution and support from probation officers and social caseworkers.

For the speed up the probation service, adequate number of probation officers should be appointed at local level for the betterment of the children. The government should focus on children court, child and welfare board, CDC and diversion programs. CDC can offer workshops for the parents involving the children for changing the old punitive parenting style.

Finally, it is highly important to introduce some alternatives measures such as, bail, conditional discharge, suspension of sentence, probation, community service, compensation, restitution. Modern rehabilitation programs with living guidance can be introduced for the children especially for trauma victims, psychological cases, the drug and alcohol addicts to restore the delinquent back to normal living and to develop his personality. It is also important to train up the persons concerned in the child protection system so that proper implementation of the Act 2013 can be ensured. Therefore, an ethical approach must be taken by all concerned to ensure that the children of this country may achieve the fulfillment of their rights.

On the contrary, in the Malaysian context, there should be amended to the Act 2001 in order to include more detailed provisions on arrest, investigation, custody, and police conduct and statement of sentencing principles, with explicit reference to the principle of best interest. Additionally, the State should develop and implement a comprehensive system of alternative measures of deprivation of liberty, such as probation, community service orders and suspended sentences, in order to ensure that deprivation of liberty is used only as a measure of last resort. Consequently, it is necessary to build the skills and capacity of probation officers in order to develop structured, written intervention plans for the children, subject to community orders, which are based upon a comprehensive assessment of both the children and family.

${ }^{103}$ BSAF (Child Rights Forum of Bangladesh) Report, December 2017. 
Prohibition of life imprisonment and indefinite detention, and setting a maximum term of imprisonment should be fixed in line with international standards. Furthermore, it is needed to established specialized police units in major cities to deal with all child suspects and child specialists in other locations. The involvement of probation officers from the point of arrest to facilitate a bail or an appropriate pre-trial release alternative should be ensured.

In terms of child-friendly justice for both countries, the children should be treated with compassion and respect for their dignity in the family, school and community which support them for reinsertion and rehabilitation. It is also necessary to consider establishing alternative facilities for dealing with arrested children. In this context, parent's guidance and education can bring changes among offender children and youth. Education does solve their problems and creates awareness about social values as well as provide the ways to achieve the peace building for the nation.

\section{b. Application of Ethics Practice in the Justice System}

In recent times, lack of professional ethics of concerned authorities (such as police, courts, and corrections); the children do not get improved social services from them. Within the juvenile justice system, ethics is relevant to most management and policy decisions relating to punishment. Hence, for the part of the justice system that addresses the provision of protection of children and youth should include ethics systems. ${ }^{104}$ Each country needs to consider its own circumstances in this respect.

In Bangladesh and Malaysia, a set of national standards for the protection of children and youth has been developed to set the framework for the administration of juvenile justice. Ethical standards are highly important for the country to provide value-based treatment of child and youth offenders in all stages of justice. Equally, there is needed to develop the code of ethics in the legal system and for which there is no other alternative but raising the knowledge of legal and judicial professionals with regard to ethics, professional responsibility and accountability. ${ }^{105}$

The people who are working with offender children have a responsibility for the services they offer directly to the children and young people in their care and protection. They have a responsibility towards their immediate colleagues and other professionals with whom they need to collaborate in the interests. In the contents of a code of ethics for childcare workers, therefore, the emphasis should be upon the needs of children and their families, and upon the ways in which those needs may best be met. Codes should spell out why children and meeting their needs are important, strengthening the motivation of childcare workers to carry out their work effectively and reinforcing their professional values, such as respect, care and concern for the children and

${ }^{104}$ Muncie, J. (2009). The United Nations, Children's Rights and Juvenile Justice. Youth Justice Handbook: Theory, policy and practice, 20-21.

${ }_{105}$ Nahid Ferdousi, (2014) Legislative Action for Protection of Juvenile Offenders in Malaysia and Bangladesh: An Overview, Journal of Malaysian and Comparative Law, vol. 41, no. 1. pp. 125 - 140. 
families with whom they work. Hence, ethics is crucial in decisions involving discretion, force, and due process, because juvenile justice professionals can be tempted to abuse their powers. ${ }^{106}$

\section{CONCLUSION}

The UNCRC contains several provisions calling upon the State Parties to ensure an effective juvenile justice system. In many parts of the world, there is recognition of the importance to improve and reform the juvenile justice system. The Bangladesh and Malaysia juvenile justice norms, laws and practice have been reformed as per international principles. Though it is the obligation of the State to provide accessible justice to all children but that not indicate that all justice should be dispensed through the formalized structures only. In this context, for providing appropriate and competent service for the children in the juvenile justice system, professionals must be aware of the legal and ethical expectations and constraints. It must be remembered that the justice system should always emphasize the wellbeing of the child and ensure that any punishment of child offenders is always in proportion to the circumstances of both the offenders and the offense. For both the countries, there is a need of establishing a child-friendly justice system, which would recognize the child as subject to fundamental rights and freedom and to ensure that all actions concerning the child are done for her/his best interest.

\section{REFERENCE}

Wahid, J., \& United Nations Asia and Far East Institute for the Prevention of Crime and Treatment of Offenders. (1978). Treatment of Juvenile Delinquents and Youthful Offenders In Malaysia (From Unafei-Resource Material Series No 14, 1978, SEE NCJ-51514).

Ali, M. I. (2010). Towards a Justice Delivery System for Children in Bangladesh: A guide and Case law on Children in Conflict with the Law. UNICEF Bangladesh.

Child Protection and Child Welfare Services in Malaysia, Beijing High Level Meeting, Ministry of Women, Family and Community Development, November 4-6, 2010, 2.

Child Protection System in Malaysia: An Analysis of the System for Prevention and Response to Abuse, Violence and Exploitation against Children (Draft), Ministry of Women, Family and Community Development 2010.

Dusuki, F. N. (2009) The UN Convention on the Rights of the Child and The Administration of Juvenile Justice. An Examination of the Legal Framework in Malaysia, Asia Law Quarterly, Vol. 1, No.1: 141.

Ferdousi, Nahid, The Children Act, 2013: A Milestone of Child Protection in Bangladesh, The Daily Star, 24 September 201312.

${ }^{106}$ Islam, M. R., Sikder, M., \& Islam, A. (2014). Effectiveness Of Legal And Institutional Framework For Juvenile Justice In Bangladesh: A Critical Analysis. Social Research Reports, 26. vol. 26, pp. 66-81. 
Ferdousi, Nahid (2014). Legislative Action for Protection of Juvenile Offenders in Malaysia and Bangladesh: An Overview, Journal of Malaysian and Comparative Law, vol. 41, no. 1., $125-140$.

Ferdousi, Nahid. (2015). The establishment of children's courts in Bangladesh: from principle to practice, Oxford University Commonwealth Law Journal, 15:2, 197-221.

Hoque, M. E. (2009). Best Interest of the Children. Dhaka: Academic Press and Publishers Library, 3, 21.

Islam, M. R., Sikder, M., \& Islam, A. (2014). Effectiveness Of Legal And Institutional Framework For Juvenile Justice In Bangladesh: A Critical Analysis. Social Research Reports, 26. vol. 26, pp. 66-81.

Khan, B. U., \& Rahman, M. M. (2008). Protection of Children in Conflict with the Law in Bangladesh. Save the Children UK, Bangladesh Programme.

McShane, M. D., \& Williams III, F. P. (Eds.). (2002). Encyclopedia of juvenile justice. SAGE Publications.

Muncie, J. (2009). The United Nations, Children's Rights and Juvenile Justice. Youth Justice Handbook: Theory, policy and practice, 20-21.

Pham, T. T. N. (2013). The establishment of juvenile courts and the fulfilment of Vietnam's obligations under the convention on the rights of the child. Australian Journal of Asian Law, 14(1).

Shaikh, M. A. (1988). Ethics of Decision-Making in. American Journal of Islamic Social Sciences 5: 1, 5(1), 115.

Rahman, W. U., \& Shahabuddin, M. (Eds.). (2005). Judicial Training in the New Millennium: An Anatomy of BILIA Judicial Training with Difference. Bangladesh Institute of Law and International Affairs.

Suo Moto Order No.248, 2003; 11 BLT 2003 HCD 281.

59 Dhaka Law Reports (DLR) 2007, 72.

Laws of Malaysia, The Child Act 2001, Act No. 611.

The Children Act 2013 (Act no. 26 of 2013).

The Children Rules, Elimination of child labour, protection of children and young persons, BGD1976-R-75121

The Constitution of Bangladesh 1972

The National Policy on Child Protection and Action Plan 2009.

The National Policy on Children and Action Plan 2009.

Laws of Malaysia, Penal Code, Act 574

Laws of Malaysia, The Police Act 1967 (Act No. 344)

The Probation of Offenders Ordinance 1960 (Ordinance No.XLV of 1960)

The United Nations Convention on the Rights of the Child (UNCRC), 1989 
The United Nations Rules for the Protection of Juveniles Deprived of their Liberty 1990.

Rules, Beijing. (1985). United Nations Standard Minimum Rules for the Administration of Juvenile Justice. Adopted by the General Assembly on, 29.

UNCRC Committee (2008) 'Third and fourth periodic reports of Bangladesh submitted to the Convention on the Rights of the Child', CRC/C/BGD/4, 23 October 2008, 31 (accessed on 19 March 2014).

UNICEF. (1998). Innocenti Digest No. 3. Juvenile Justice Unicef: Florence.

UNICEF. (2013). The Malaysian juvenile justice system: a study of mechanisms for handling children in conflict with the law. Ministry of Women, Family and Community Development and UNICEF Malaysia.

www.msw.gov.bd 